Research Article

\title{
Public perceptions for managing coastal hazards- study on Indian sundarbans
}

\begin{abstract}
Community perception becomes a central issue for hazard mitigation of an area. Present study made an attempt to assess public opinion regarding various problems associated with life and livelihood of Sundarbans. A survey was conducted over 254 households located along 22 mangrove fringe villages of Kultali, Gosaba and Hingalganj. Waterlogging, erosion, salinity, storm surges and embankment breaching are the major challenges identified during the survey. Details account of causes, consequences and their spatial extension have been presented and future coping strategies are also recommended. Elevating houses (92\%), green buffering (80\%) and construction of pucca house $(9.8 \%)$ are the desired coping strategies for different hazards. Regarding future strategies, $48 \%$ like to stay if Govt. initiated for hazard mitigation and $37 \%$ like to live with the disaster.
\end{abstract}

Volume 9 Issue 6 - 2020

\section{Rakesh Bera, Ramkrishna Maiti}

Department of Geography,Vidyasagar University, India

Correspondence: Rakesh Bera, Department of Geography, Vidyasagar University, India,

Email rge_rakesh@mail.vidyasagar.ac.in

Received: October 14, 2020 | Published: December 31, 2020

Keywords: perception, hazard, coping strategies, green buffering, hazard mitigation

\section{Introduction}

Coast provides essential needs for human habitation and historically it acts as a focal point for human development. ${ }^{1}$ In recent time coastal regions are highly affected by SLR, erosion, storm surges, subsidence, pollution, ground water degradation, waterlogging and associate hazards. Long term management of coast is essential, it is highly challenging though. Strong dichotomy regarding coastal protection maintaining the use of natural resources, conservation of mangrove without restricting people from their NTFP collection are giving strong challenges to the planners and coastal managers.

Community perception or community attitude towards hazard became a central issue for disaster management. ${ }^{2}$ Public participation has become the simplest way to achieve sustainable development by overwhelming various environmental and developmental constrains. ${ }^{3}$ People for the implementation of those management strategies should have awareness of that. Any protection or restriction can't be successful without people's co-operation. ${ }^{3,4}$ For long term sustainability of any management, people have to realize its extended utility and came forward for its implementation with active co-operation.

In most of the cases management or legislation did not succeed because of people non-co-operational mentality. They always look that as a restriction over them through which their livelihood options becoming limited. So, for the successful management, coastal people should have to include in the process of decision making and if any restrictions or laws adopted, they have given the responsibility to implement them for their own necessity.

\section{Study area}

The study have been conducted over 22 mangrove fringe villages located at Hingalganj (04), Gosaba (13) and Kultali (05) of South 24 Paraganas (Figure 1). Around 254 sample households were surveyed. Majority of the households resided either over the bank or within few metres fromthe tidal channels. Selection was based on the location, level of development and risk intensity.

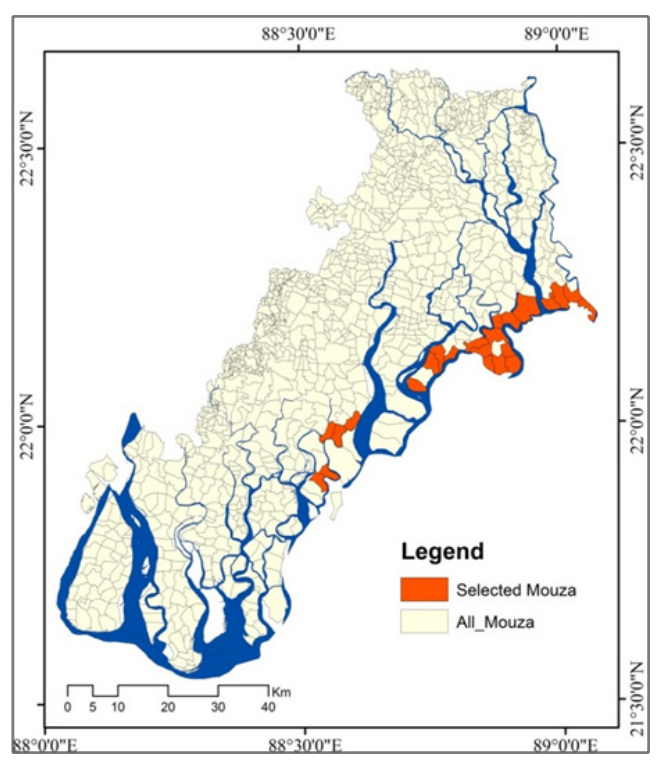

Figure I Location of sample villages for the assessment of livelihood assets.

\section{Methodology}

\section{Sample selection}

To carry out the research work a questionnaire was prepared based on the model study (DSAS for coastal erosion, NDSSI and SSC from Landsat TM imageries, Mudflat expansion from NDVI and LSWI model, Waterlogging from LSWI, Mangrove destruction from NDVI, Risk perception from CRI) and existing literatures to assess people's knowledge/perception/felling/attitude about various changes that have been taken place to their locality. It has been considered that people, who are living at the margin of the main mangrove, have the best experience on the changing processes of this area. Fringe villagers, those are involved in fishing or NTFP collection have spent most of their time inside the mangrove and considered to be the best 
interpreters of nature and natural processes. From the viewpoint of risk and vulnerability, marginal areas were historically suffered from multiple stresses. In this regards we selected 22 fringe villages of Kultali, Gosaba and Hingalganj for the survey.

\section{Data Collection through sample survey}

Household survey was conducted from June 2018 to December 2018. Mostly Jetty Ghats (where boats are landed) have been chosen for the survey. We travelled along the channel from one village to another. We involved local people like Srikrishna, Arjun, Shyam from Deulbari Debipur (Kultali), Rahul from Samsernagar (Hingalganj) for the survey. Local language has been used for the communication during the survey. Total 254 households have been surveyed and for every household question were asked to the available senior most person as well as the person who regularly visited to the forest.

\section{Data Analysis}

The collected data were systematically arranged in accordance to the objectives of the study. After that, we transformed all responses into quantitative format based on the different scientific scale (Table 1). The issues are classified and statistical analyses were conducted using SPSS and Microsoft Excel.

Table I Five point opinion scale

\begin{tabular}{ll}
\hline Opinion & Score \\
\hline Strongly disagree & $\mathrm{I}$ \\
Disagree & 2 \\
Neutral & 3 \\
Agree & 4 \\
Strongly disagree & 5 \\
\hline
\end{tabular}

\section{Results and discussion}

\section{General Description of the Respondents}

Among the 254 households from 22 villages, most popular occupations were noted to be Cultivation and Crab Collection which contributed $37 \%$ and $31 \%$ respectively. Areas like Bijoynagar, Kalidaspur, Deulbari Debipur and Samsernagar have more than 50\% respondents whose primary occupation was crab collection. Most of the respondents were edged (Ave. age 50) and male (97.64\%) with an average habitation age of 60 years.

\section{Perception on Coastal Hazards and their Management Options}

Similar to the academician, planners and other experts, the local inhabitants also have strong perception regarding the environmental changes or the problems emerged during their life period. Respondents were asked to state the type of changes they have seen in their surroundings, which factors were responsible for that and what consequences are associated with those changes. The most common issues that were identified are discussed below.

\section{Waterlogging}

Recently waterlogging becomes a very common problem of low lying coastal areas. Insufficiency of drainage sometimes increases the severity of this problem. Indian parts of Sundarbans have elevation less than 3 metre, along with that most of the drainage and sluice gate became non-functional now as a result of subsidence induced sea level rise.

\section{(I) Perceived changes in waterlogged area}

People were asked to response on the spatial expansion of waterlogged areas throughout their life time and what they would think to be responsible for that. About 51\% respondents were strongly agreed with the addition of permanent waterlogged area. In comparison to that only $13 \%$ respondents preferred the decreasing option. Though about $36 \%$ respondents preferred unchanged option (Figure 2a).
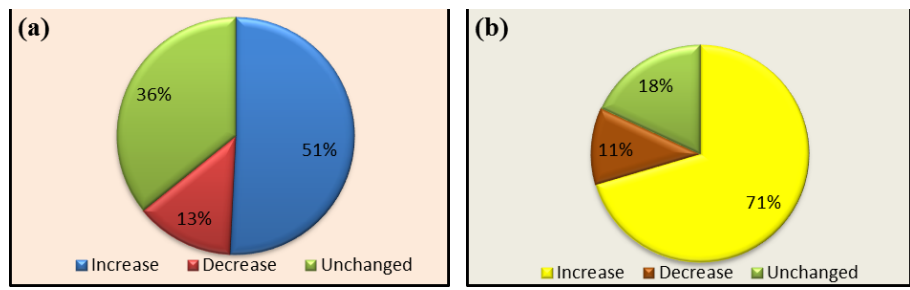

Figure 2 Changes in waterlogged Areas (a) Permanent (b) Seasonal.

Most of the respondents stated that waterlogging has been increased and it is more common in Monsoon and Post-Monsoon months. They also specified that it has been adversely affected their livelihood. In response to seasonal change of waterlogging, a large proportion of respondents $(71 \%)$ strongly agreed with the increasing option. Only $11 \%$ respondents supported the decreasing option and $18 \%$ felt that it remains unchanged (Figure 2b). Most of the respondents from Bijaynagar, Binodpur, DeulbariDebipur, Hemnagar, Hetalbari, Kalitala, Luxbagan, Madhya Gurguria, Maipith, PurbaGurguria and Sadhupur were strongly agreed with the increase of permanent waterlogged areas. Respondents from Bally, Dayapur, Hamilton Abad, Kalidaspur, Kumirmari, Pakhiralay and Paraghumti stated that they have not seen any changes of permanent waterlogged area. A mixed response marginally favoured the increase of waterlogging came from Samsernagar (Figure 3a)

In case of seasonal waterlogging, the respondents were dominantly agreed with the increasing option. Only Kumirmari haveopposite response and all 10 respondents from this village stated that waterlogged areas are significantly decreasing significantly. Mixed response came from villages like Bally, Hetalbari, Kalidaspur, Mathurakanda, Pakhiralay and Sonagar (Fig. 3b).
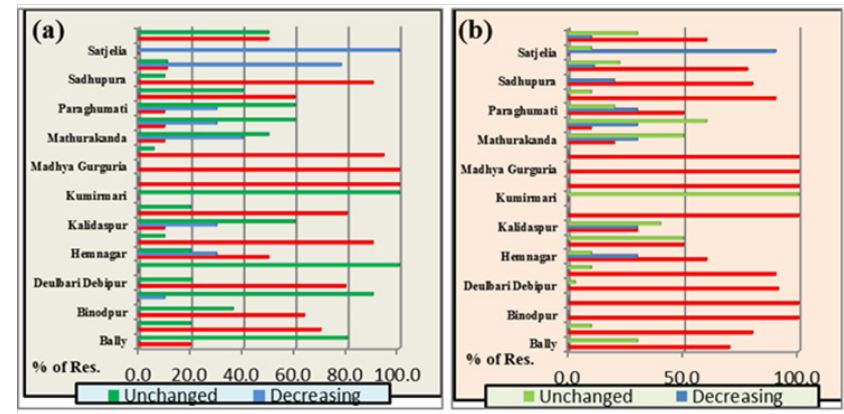

Figure 3 Response on changes of waterlogged areas (a) Permanent (b) Seasonal.

\section{(II) Perception on responsible factors for waterlogging}

During the pilot survey, people were asked to specify the factors responsible for waterlogging. They can choose more than one options if required. Insufficient Drainage, Lower Elevation, Rising Tidal Height and Lack of Sluice were the main factors identified by the respondents. During the main survey these four options were represent 
in front of the respondents and ask for their opinion. More than $87 \%$ respondents strongly believed that lower elevation is the main reason for waterlogging. Along with that Insufficient Drainage (69.29\%), Lack of active Sluice (51.97\%) and Rising Tide (42.52\%) were also significantly contributed in the process of waterlogging (Figure 4).

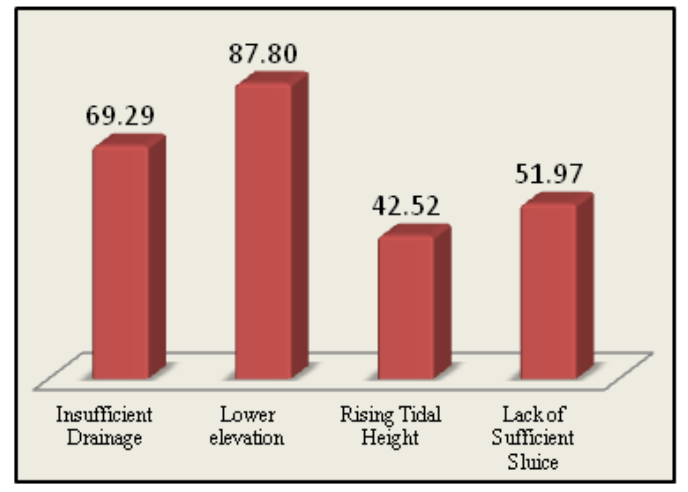

Figure 4 Responsible factors for waterlogging.

Village wise responses alsodisclose that lower elevation is the main factor for waterlogging. Insufficient drainage is also largely responsible for waterlogging in most of the villages except Bijaynagar, Dayapur, Hamilton Abad, Mathurakanada, Pakhiralay and Satjelia. Others two factors also have significant contribution in waterlogging. In various cases people said that all four have more or less equally contributed to that problem (Figure 5).

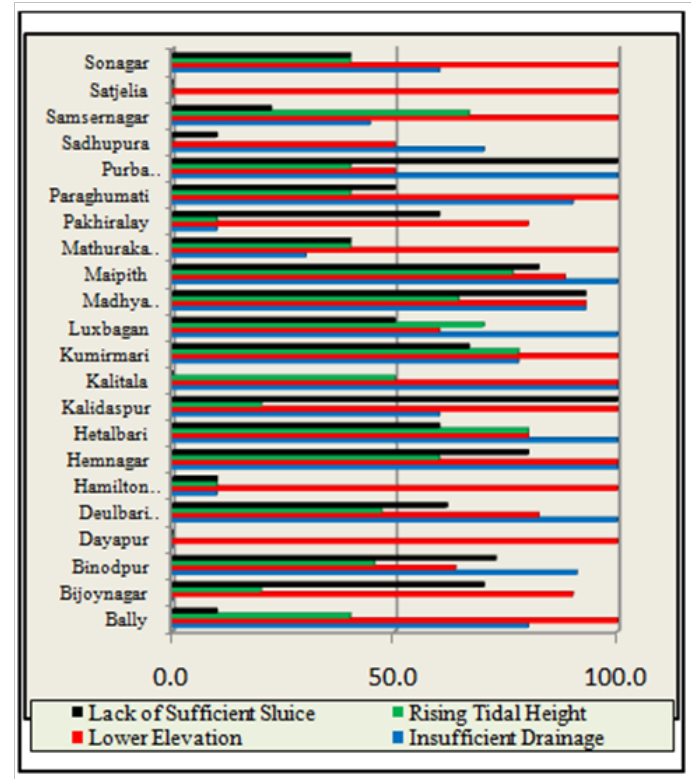

Figure $\mathbf{5}$ Village wise perceived causes for waterlogging.

\section{(III) Perception on consequences of waterlogging}

A set of close ended question concerning the consequences of waterlogging were submitted to the respondents and ask for their opinion. The summery of 254 responses indicated that fishery expansion was the most common problem associated with waterlogging. About $96.46 \%$ respondents strongly believed that fishery expansion, especially over the agricultural land is directly connected with the waterlogging. Health problems, especially chronicity of various fever and diaries also relatedto the dirty waterlogged areas. About $33 \%$ respondents concerned about the loss of connectivity (Figure 6).

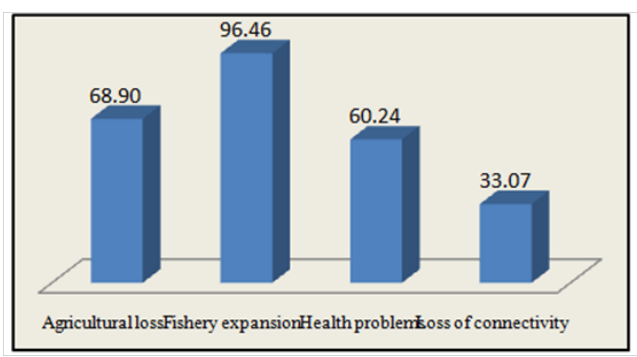

Figure 6 Major consequences of waterlogging.

Leading consequences of waterlogging varies among villages. Most of the respondents from Bally, Binodpur, Deulbari Debipur, Kalitala, Madhya Gurguria, PurbaGurguria and Hingalganj strongly agreed that agricultural loss and fishery expansion have been largely associated with waterlogging. Expansion of fishery was the leading response for villages like Dayapur, Hamilton Abad, Kumirmari, Mathurakanda, Satjelia and Sonagar. For Bijaynagar, Luxbugan and Pakhiralay both health problems and fishery expansion have got highest response. Mixed response came from villages like Hemnagar, Hetalbari, Kalidaspur, Maipith and Sadhupur (Table 2)

\section{Soil Salinity}

Low lying coastal regionsare highly affected by salinity and its magnitude now reached beyond the tolerance limits in most of the regions. The effect of salinity on agriculture is a popular issue for scientific discussion. Land affected by salinity is always associated with less productivity or crop failure. People responses regarding salinity gave an outline of actual severity.

Majority of the respondents replied that the salinity level of their locality is under very high (44.88\%) and high $(33.07 \%)$ categories. Only $2.76 \%$ respondents perceived lower level of salinity. Overall result indicated salinity problem of this region (Figure 7).

Based on the survey responses Dayapur, Deulbaridebipur, Hamilton Abad, Hetalbari, Kalitala, Maipith and Samsernagar were identified as very high salinity affected areas. High perceived salinity was also identified by the villagers of Bally, Luxbagan and Sadhupur. Kumirmari and Paraghumti placed in between high to very high salinity level. Rest of the villages were identified as moderate to low salinity categories (Table 3).

\section{(I) Perception on time since salinity problem arises}

People were asked to remember the time since salinity problem came into their life. Majority of the responses either choose 10 years option (53.54\%) or stated salinity as a traditional problem $(42.52 \%)$ (Figure 8). Most of the respondents also clarified that the Aila Cyclone of 2009 has been highly responsible for the degradation of their good agricultural land.

Majority of the respondents from all villages except Binodpur, Maipith, Pakhiralay, Purba Gurguria, Sadhupur and Satjelia were strongly agreed with that the salinity problem is an all-time issue of their locality. On the other hand most of respondents from Pakhiralay, Satjelia and PurbaGurguria believed that Salinity problem arise in last 10 years. In Maipith people stated that it has been realized in last 5 years. From the above statistics we can sum up that like other coastal reclaimed lowland, in Sundarbans the problem of salinity is a long term issue and there is no doubt about that. However it has been increased in a certain extent and started to impact over the livelihood options (Agriculture, Fishing, NTFP collection etc.) in last 10 years. That was realized by majority of the inhabitants especially the fringe villagers (Table 4). 
Table 2 Village wise opinion score on consequences of water logging

\begin{tabular}{|c|c|c|c|c|c|c|c|c|c|c|c|c|}
\hline \multirow{2}{*}{$\begin{array}{l}\text { SI } \\
\text { No }\end{array}$} & \multirow{2}{*}{ Block } & \multirow{2}{*}{$\begin{array}{l}\text { Name of } \\
\text { the Hab. }\end{array}$} & \multirow{2}{*}{$\begin{array}{l}\text { No of } \\
\text { Sample } \\
\text { Hab. }\end{array}$} & \multirow{2}{*}{$\begin{array}{l}\text { Mean } \\
\text { age } \\
\text { of the } \\
\text { Hab. } \\
(Y r)\end{array}$} & \multicolumn{2}{|c|}{$\begin{array}{l}\text { Agricultural } \\
\text { Loss }\end{array}$} & \multicolumn{2}{|c|}{$\begin{array}{l}\text { Fishery } \\
\text { expansion }\end{array}$} & \multicolumn{2}{|c|}{$\begin{array}{l}\text { Health } \\
\text { problems }\end{array}$} & \multicolumn{2}{|c|}{$\begin{array}{l}\text { Loss of } \\
\text { connectivity }\end{array}$} \\
\hline & & & & & $\begin{array}{l}\text { No } \\
\text { of } \\
\text { Res. }\end{array}$ & $\begin{array}{l}\% \text { of } \\
\text { T.Res. }\end{array}$ & $\begin{array}{l}\text { No } \\
\text { of } \\
\text { Res. }\end{array}$ & $\begin{array}{l}\% \text { of } \\
\text { T.Res. }\end{array}$ & $\begin{array}{l}\text { No } \\
\text { of } \\
\text { Res. }\end{array}$ & $\begin{array}{l}\% \text { of } \\
\text { T.Res. }\end{array}$ & $\begin{array}{l}\text { No } \\
\text { of } \\
\text { Res. }\end{array}$ & $\begin{array}{l}\% \text { of } \\
\text { T.Res. }\end{array}$ \\
\hline I & Gosaba & Bally & 10 & 53 & 7 & 70.0 & 10 & 100.0 & 5 & 50.0 & 3 & 30.0 \\
\hline 2 & Gosaba & Bijoynagar & 10 & 54.4 & 2 & 20.0 & 9 & 90.0 & 8 & 80.0 & 0 & 0.0 \\
\hline 3 & Kultali & Binodpur & 11 & 71 & 10 & 90.9 & 10 & 90.9 & 6 & 54.5 & 3 & 27.3 \\
\hline 4 & Gosaba & Dayapur & 10 & 60.7 & 1 & 10.0 & 10 & 100.0 & 0 & 0.0 & 0 & 0.0 \\
\hline 5 & Kultali & $\begin{array}{l}\text { Deulbari } \\
\text { Debipur }\end{array}$ & 34 & 69.2 & 31 & 91.2 & 32 & 94.1 & 17 & 50.0 & 13 & 38.2 \\
\hline 6 & Gosaba & $\begin{array}{l}\text { Hamilton } \\
\text { Abad }\end{array}$ & 10 & 62.4 & 1 & 10.0 & 10 & 100.0 & 1 & 10.0 & 1 & 10.0 \\
\hline 7 & Hingalganj & Hemnagar & 10 & 66.6 & 9 & 90.0 & 10 & 100.0 & 10 & 100.0 & 5 & 50.0 \\
\hline 8 & Gosaba & Hetalbari & 10 & 63 & 10 & 100.0 & 10 & 100.0 & 10 & 100.0 & 8 & 80.0 \\
\hline 9 & Gosaba & Kalidaspur & 10 & 57.18 & 10 & 100.0 & 14 & 100 & 13 & 100 & 2 & 20.0 \\
\hline 10 & Hingalganj & Kalitala & 10 & 55.3 & 8 & 80.0 & 9 & 90.0 & 5 & 50.0 & 5 & 50.0 \\
\hline II & Gosaba & Kumirmari & 9 & 65.77 & 7 & 77.8 & 9 & 100.0 & 7 & 77.8 & 6 & 66.7 \\
\hline 12 & Gosaba & Luxbagan & 10 & 52.5 & 6 & 60.0 & 8 & 80.0 & 8 & 80.0 & 6 & 60.0 \\
\hline 13 & Kultali & $\begin{array}{l}\text { Madhya } \\
\text { Gurguria }\end{array}$ & 14 & 53.7 & 13 & 92.9 & 14 & 100.0 & 6 & 42.9 & 3 & 21.4 \\
\hline 14 & Kultali & Maipith & 17 & 66 & 15 & 88.2 & 15 & 88.2 & 8 & 47.1 & 14 & 82.4 \\
\hline 15 & Gosaba & Mathurakanda & 10 & 51.7 & 3 & 30.0 & 10 & 100.0 & 5 & 50.0 & 0 & 0.0 \\
\hline 16 & Gosaba & Pakhiralay & 10 & 59 & 1 & 10.0 & 10 & 100.0 & 8 & 80.0 & 0 & 0.0 \\
\hline 17 & Hingalganj & Paraghumati & 10 & 61.5 & 9 & 90.0 & 10 & 100.0 & 6 & 60.0 & 4 & 40.0 \\
\hline 18 & Kultali & $\begin{array}{l}\text { Purba } \\
\text { Gurguria }\end{array}$ & 10 & 61.3 & 10 & 100.0 & 10 & 100.0 & 4 & 40.0 & 3 & 30.0 \\
\hline 19 & Gosaba & Sadhupura & 10 & 58.6 & 6 & 60.0 & 6 & 60.0 & 9 & 90.0 & 2 & 20.0 \\
\hline 20 & Hingalganj & Samsernagar & 9 & 54.5 & 9 & 100.0 & 9 & 100.0 & 7 & 77.8 & I & II.I \\
\hline 21 & Gosaba & Satjelia & 10 & 58 & 1 & 10.0 & 10 & 100.0 & 6 & 60.0 & 4 & 40.0 \\
\hline 22 & Gosaba & Sonagar & 10 & 47.6 & 6 & 60.0 & 10 & 100.0 & 4 & 40.0 & 1 & 10.0 \\
\hline \multicolumn{3}{|l|}{ Sum } & \multicolumn{2}{|l|}{254} & \multicolumn{2}{|l|}{175} & \multicolumn{2}{|l|}{245} & \multicolumn{2}{|l|}{153} & \multicolumn{2}{|l|}{84} \\
\hline \multicolumn{3}{|c|}{$\%$ of Total Respondents } & \multicolumn{2}{|l|}{100} & \multicolumn{2}{|l|}{68.90} & \multicolumn{2}{|l|}{96.46} & \multicolumn{2}{|l|}{60.24} & \multicolumn{2}{|l|}{33.07} \\
\hline
\end{tabular}

Table 3 Village-wise perceived level of salinity

\begin{tabular}{lllllllllll}
\hline SI No & Name of the Village & $\begin{array}{l}\text { No of } \\
\text { Sample } \\
\text { Hab. }\end{array}$ & $\begin{array}{l}\text { Very High } \\
\text { No of } \\
\text { Res. }\end{array}$ & $\begin{array}{l}\text { \% of T. } \\
\text { Res. }\end{array}$ & $\begin{array}{l}\text { Ho of } \\
\text { Res. }\end{array}$ & $\begin{array}{l}\text { Moderate } \\
\text { Res. }\end{array}$ & $\begin{array}{l}\text { Low } \\
\text { Rof } \\
\text { Res. }\end{array}$ & $\begin{array}{l}\text { \% of T. } \\
\text { Res. }\end{array}$ & $\begin{array}{l}\text { No of } \\
\text { Res. }\end{array}$ & $\begin{array}{l}\text { \% of T. } \\
\text { Res. }\end{array}$ \\
\hline I & Bally & 10 & 2 & 20.0 & 8 & 80.0 & 0 & 0.0 & 0 & 0.0 \\
2 & Bijoynagar & 10 & 0 & 0.0 & 6 & 60.0 & 4 & 40.0 & 0 & 0.0 \\
3 & Binodpur & 11 & 2 & 18.2 & 3 & 27.3 & 3 & 27.3 & 3 & 27.3 \\
4 & Dayapur & 10 & 7 & 70.0 & 3 & 30.0 & 0 & 0.0 & 0 & 0.0 \\
5 & DeulbariDebipur & 34 & 32 & 94.1 & 1 & 2.9 & 1 & 2.9 & 0 & 0.0 \\
6 & Hamilton Abad & 10 & 7 & 70.0 & 3 & 30.0 & 0 & 0.0 & 0 & 0.0 \\
\hline
\end{tabular}


Table continued...

\begin{tabular}{|c|c|c|c|c|c|c|c|c|c|c|}
\hline \multirow[b]{2}{*}{ SI No } & \multirow[b]{2}{*}{ Name of the Village } & \multirow{2}{*}{$\begin{array}{l}\text { No of } \\
\text { Sample } \\
\text { Hab. }\end{array}$} & \multicolumn{2}{|c|}{ Very High } & \multicolumn{2}{|l|}{ High } & \multicolumn{2}{|c|}{ Moderate } & \multicolumn{2}{|l|}{ Low } \\
\hline & & & $\begin{array}{l}\text { No of } \\
\text { Res. }\end{array}$ & $\begin{array}{l}\% \text { of T. } \\
\text { Res. }\end{array}$ & $\begin{array}{l}\text { No of } \\
\text { Res. }\end{array}$ & $\begin{array}{l}\% \text { of T. } \\
\text { Res. }\end{array}$ & $\begin{array}{l}\text { No of } \\
\text { Res. }\end{array}$ & $\begin{array}{l}\% \text { of T. } \\
\text { Res. }\end{array}$ & $\begin{array}{l}\text { No of } \\
\text { Res. }\end{array}$ & $\begin{array}{l}\% \text { of T. } \\
\text { Res. }\end{array}$ \\
\hline 7 & Hemnagar & 10 & 2 & 20.0 & 5 & 50.0 & 3 & 30.0 & 0 & 0.0 \\
\hline 8 & Hetalbari & 10 & 8 & 80.0 & 2 & 20.0 & 0 & 0.0 & 0 & 0.0 \\
\hline 9 & Kalidaspur & 10 & 1 & 10.0 & 3 & 30.0 & 6 & 60.0 & 0 & 0.0 \\
\hline 10 & Kalitala & 10 & 10 & 100.0 & 0 & 0.0 & 0 & 0.0 & 0 & 0.0 \\
\hline II & Kumirmari & 9 & 5 & 55.6 & 4 & 44.4 & 0 & 0.0 & 0 & 0.0 \\
\hline 12 & Luxbagan & 10 & 0 & 0.0 & 10 & 100.0 & 0 & 0.0 & 0 & 0.0 \\
\hline 13 & Madhya Gurguria & 14 & 8 & 57.1 & 4 & 28.6 & 2 & 14.3 & 0 & 0.0 \\
\hline 14 & Maipith & 17 & 13 & 76.5 & 2 & 11.8 & 2 & 11.8 & 0 & 0.0 \\
\hline 15 & Mathurakanda & 10 & 5 & 50.0 & 2 & 20.0 & 3 & 30.0 & 0 & 0.0 \\
\hline 16 & Pakhiralay & 10 & 0 & 0.0 & 0 & 0.0 & 7 & 70.0 & 3 & 30.0 \\
\hline 17 & Paraghumati & 10 & 2 & 20.0 & 6 & 60.0 & 2 & 20.0 & 0 & 0.0 \\
\hline 18 & PurbaGurguria & 10 & 4 & 40.0 & 5 & 50.0 & 1 & 10.0 & 0 & 0.0 \\
\hline 19 & Sadhupura & 10 & 0 & 0.0 & 9 & 90.0 & 1 & 10.0 & 0 & 0.0 \\
\hline 20 & Samsernagar & 9 & 6 & 66.7 & 0 & 0.0 & 2 & 22.2 & 1 & 11.1 \\
\hline 21 & Satjelia & 10 & 0 & 0.0 & 3 & 30.0 & 7 & 70.0 & 0 & 0.0 \\
\hline 22 & Sonagar & 10 & 0 & 0.0 & 5 & 50.0 & 5 & 50.0 & 0 & 0.0 \\
\hline
\end{tabular}

Table 4 Village wise perceived response on time from which salinity problems arise

\begin{tabular}{|c|c|c|c|c|c|c|c|c|c|c|}
\hline \multirow[b]{2}{*}{ SI No } & \multirow{2}{*}{$\begin{array}{l}\text { Name of the } \\
\text { Village }\end{array}$} & \multirow{2}{*}{$\begin{array}{l}\text { No of } \\
\text { Sample } \\
\text { Hab. }\end{array}$} & & \multicolumn{2}{|c|}{ Last 5 years } & \multicolumn{2}{|c|}{ Last 10 years } & \multicolumn{2}{|c|}{ Last 20 years } \\
\hline & & & $\begin{array}{l}\text { No of } \\
\text { Res. }\end{array}$ & & $\begin{array}{l}\text { No of } \\
\text { Res. }\end{array}$ & $\begin{array}{l}\% \text { of } \\
\text { T.Res. }\end{array}$ & $\begin{array}{l}\text { No of } \\
\text { Res. }\end{array}$ & $\begin{array}{l}\% \text { of T. } \\
\text { Res. }\end{array}$ & $\begin{array}{l}\text { No of } \\
\text { Res. }\end{array}$ & $\begin{array}{l}\% \text { of T. } \\
\text { Res. }\end{array}$ \\
\hline I & Bally & 10 & 10 & 100.0 & 0 & 0.0 & 0 & 0.0 & 0 & 0.0 \\
\hline 2 & Bijoynagar & 10 & 10 & 100.0 & 0 & 0.0 & 0 & 0.0 & 0 & 0.0 \\
\hline 3 & Binodpur & II & 0 & 0.0 & 0 & 0.0 & 9 & 81.1 & 0 & 0.0 \\
\hline 4 & Dayapur & 10 & 10 & 100.0 & 0 & 0.0 & 0 & 0.0 & 0 & 0.0 \\
\hline 5 & Deulbari Debipur & 34 & 28 & 82.4 & 6 & 17.6 & 0 & 0.0 & 0 & 0.0 \\
\hline 6 & Hamilton Abad & 10 & 9 & 90.0 & I & 10.0 & 0 & 0.0 & 0 & 0.0 \\
\hline 7 & Hemnagar & 10 & 10 & 100.0 & 0 & 0.0 & 0 & 0.0 & 0 & 0.0 \\
\hline 8 & Hetalbari & 10 & 9 & 90.0 & 0 & 0.0 & I & 10.0 & 0 & 0.0 \\
\hline 9 & Kalidaspur & 10 & 9 & 90.0 & 0 & 0.0 & I & 10.0 & 0 & 0.0 \\
\hline 10 & Kalitala & 10 & 10 & 100.0 & 0 & 0.0 & 0 & 0.0 & 0 & 0.0 \\
\hline 11 & Kumirmari & 9 & 8 & 88.9 & 0 & 0.0 & 1 & II.I & 0 & 0.0 \\
\hline 12 & Luxbagan & 10 & 6 & 60.0 & 0 & 0.0 & 4 & 40.0 & 0 & 0.0 \\
\hline 13 & Madhya Gurguria & 14 & 14 & 100.0 & 0 & 0.0 & 0 & 0.0 & 0 & 0.0 \\
\hline 14 & Maipith & 17 & I & 5.9 & 16 & 94.1 & 0 & 0.0 & 0 & 0.0 \\
\hline 15 & Mathurakanda & 10 & 10 & 100.0 & 0 & 0.0 & 0 & 0.0 & 0 & 0.0 \\
\hline 16 & Pakhiralay & 10 & 0 & 0.0 & I & 10.0 & 9 & 90.0 & 0 & 0.0 \\
\hline 17 & Paraghumati & 10 & 9 & 90.0 & 0 & 0.0 & I & 10.0 & 0 & 0.0 \\
\hline 18 & PurbaGurguria & 10 & 0 & 0.0 & 0 & 0.0 & 10 & 100.0 & 0 & 0.0 \\
\hline 19 & Sadhupur & 10 & 3 & 30.0 & 0 & 0.0 & 6 & 60.0 & 0 & 0.0 \\
\hline 20 & Samsernagar & 9 & 6 & 66.7 & 1 & II.I & 2 & 22.2 & 0 & 0.0 \\
\hline 21 & Satjelia & 10 & 0 & 0.0 & 5 & 50.0 & 5 & 50.0 & 0 & 0.0 \\
\hline 22 & Sonagar & 10 & 10 & 100.0 & 0 & 0.0 & 0 & 0.0 & 0 & 0.0 \\
\hline
\end{tabular}




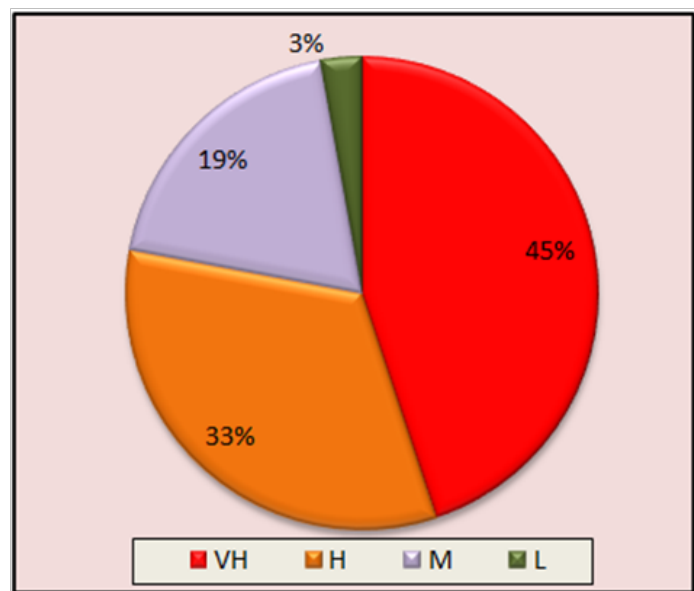

Figure 7 Perception on level of soil salinity.

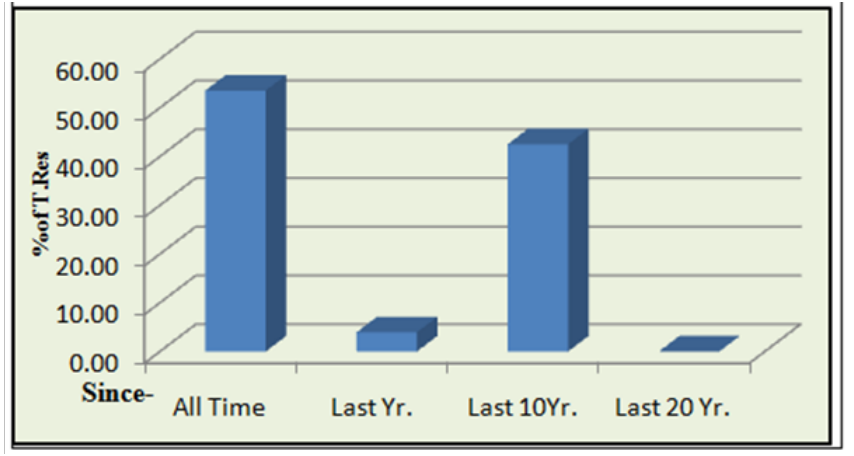

Figure 8 Salinity problem arise.

\section{(I) Perception on causes for salinity}

Respondents were asked to find out the reason behind the salinity

Table 5 Opinion score on factors responsible for salinity increase. We computed score against each factors using 5 point Likert Scale (Strongly agree=5; Strongly Disagree=1) based on the weight of responses. Among the 5 factors, embankment breaching has the highest weighted score (T.S=1230; Mean=4.88) and considered to be the most dominant causes for salinity rise. Other factors like rising tide (T.S=1175; Mean=4.66), Reduced Freshwater Supply (T.S=1172; Mean=4.67) and Aquaculture (T.S=951, Mean=3.85) also contributed significantly for the salinity rise of this area (Table 5).

\section{(II) Responses on most salinity affected sector}

In general four sectors were identified by the respondents which have been affected by salinity. Among them agriculture was the worst affected (T.S=1235; Mean=5). All the respondents considered that crop productionshave been largely hampered by higher salinity and sometimes people forced to stop cultivation in their saline land. Mangrove (T.S=382; Mean=4.66), Aquaculture (T.S=347; Mean=4.63) and Marine Fishing (T.S=338; Mean=4.45) were the other sectors affected by salinity. Top dying of Mangrove is an indication of salinity effects identified by most of the experts working on Sundarbans. Mangrove harvesters stated that in some parts of Sundarbans mangroves are highly affected by top dying problem. According to fishery workers, salinity level of their ponds increased significantly and it affected the production. In few cases they have to stop fishing due to continuous losses. Salinity level of Interior creek is also increased in a certain extent and reduces fish availability stated by Fisherman and Crab Collectors (Table 6).

\section{(III) Response on availability of management scheme}

From the accumulated responses it was clear that there were no such salinity management strategies. $96.46 \%$ respondents informed that they have nothing to do with salinity (Figure 9). Some people were either continuing their cultivation/ fishing with the use of fertilizers. In extreme condition they have converted their land into fishery or left them for longer duration.

\begin{tabular}{|c|c|c|c|c|c|c|c|c|c|c|}
\hline \multirow{2}{*}{ 站 } & \multicolumn{2}{|c|}{ Aquaculture } & \multicolumn{2}{|c|}{$\begin{array}{l}\text { Reduced Freshwater } \\
\text { Supply }\end{array}$} & \multicolumn{2}{|c|}{ Irrigation } & \multicolumn{2}{|c|}{ Rising Tide } & \multicolumn{2}{|c|}{$\begin{array}{l}\text { Embankment } \\
\text { Breaching }\end{array}$} \\
\hline & W.Sco. & $\%$ of T.Res. & W.Sco. & \% of T .Res. & W.Sco. & $\%$ of T. Res. & W.Sco. & $\%$ of T.Res. & W.Sco. & $\%$ of T. Res. \\
\hline SA & 430 & 34.82 & 920 & 73.31 & 330 & 26.19 & 955 & 75.79 & 1160 & 92.06 \\
\hline$A$ & 268 & 27.13 & 220 & 21.91 & 480 & 47.62 & 152 & 15.08 & 44 & 4.37 \\
\hline $\mathrm{N}$ & 237 & 31.98 & 30 & 3.98 & 192 & 25.40 & 66 & 8.73 & 24 & 3.17 \\
\hline$D$ & 2 & 0.40 & 0 & 0.00 & 4 & 0.79 & 2 & 0.40 & 2 & 0.40 \\
\hline SD & 14 & 5.67 & 2 & 0.80 & 0 & 0.00 & 0 & 0.00 & 0 & 0.00 \\
\hline Sum & 951 & & 1172 & & 1006 & & 1175 & & 1230 & \\
\hline Mean & 3.85 & & 4.67 & & 3.99 & & 4.66 & & 4.88 & \\
\hline
\end{tabular}

Table 6 Most salinity affected sector

\begin{tabular}{|c|c|c|c|c|c|c|c|c|c|c|}
\hline \multirow{2}{*}{ 产 } & \multicolumn{2}{|l|}{ None } & \multicolumn{2}{|c|}{ Agriculture } & \multicolumn{2}{|c|}{ Marine Fishing } & \multicolumn{2}{|c|}{ Aquaculture } & \multicolumn{2}{|c|}{ Mangrove } \\
\hline & W.Sco & $\%$ of T. Res. & W.Sco & $\%$ of T. Res. & W.Sco & $\%$ of T. Res. & W.Sco & \% of T. Res. & W.Sco & $\%$ of T. Res. \\
\hline SA & 0 & 0 & 1235 & 97.24 & 300 & 23.62 & 285 & 22.44 & 320 & 25.20 \\
\hline A & 0 & 0 & 0 & 0.00 & 0 & 0.00 & 40 & 3.94 & 32 & 3.15 \\
\hline $\mathbf{N}$ & 0 & 0 & 0 & 0.00 & 6 & 0.79 & 18 & 2.36 & 30 & 3.94 \\
\hline D & 0 & 0 & 0 & 0.00 & 32 & 6.30 & 4 & 0.79 & 0 & 0.00 \\
\hline SD & 0 & 0 & 0 & 0.00 & 0 & 0.00 & 0 & 0.00 & 0 & 0.00 \\
\hline NR & 0 & 0 & 0 & 2.76 & 0 & 69.29 & 0 & 70.47 & 0 & 67.72 \\
\hline Sum & 0 & 0 & 1235 & 100 & 338 & 100 & 347 & 100 & 382 & 100 \\
\hline Mean & 0.00 & 0.00 & 5.00 & & 4.45 & & 4.63 & & 4.66 & \\
\hline
\end{tabular}




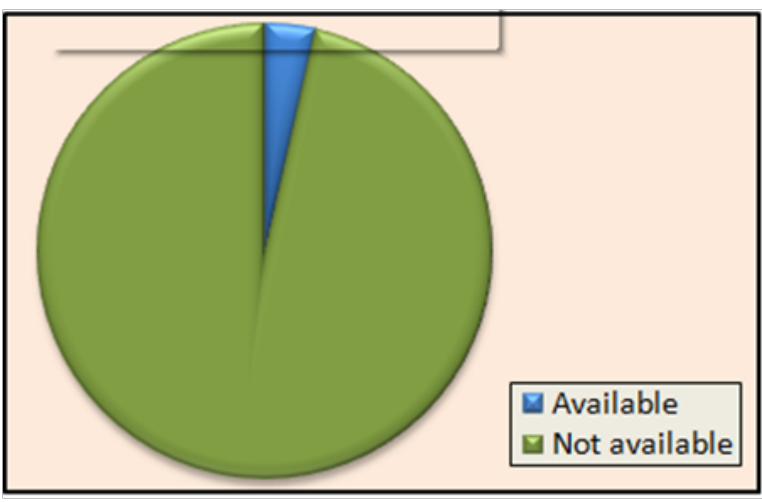

Figure 9 Availability of salinity management schemes.

\section{Embankment Breaching}

\section{(I) Areas most prone to erosion}

Respondents were asked to identify the location affected by severe erosion. It was clearly recognized that Jetty areas (T.S $=1220$; Mean=4.80; $\mathrm{S} . \mathrm{D}=0.54$ ) and Embankment without any Intertidal Area (T.S=1178; Mean=4.63; S.D=0.70) were adversely affected by erosion. Intertidal area with Dense Mangrove Cover have the lowest score 528 (Mean=2.07, S.D=0.70). The areas without Mangrove and with sparse mangrove cover have moderate score of 805 (Mean=3.16; $\mathrm{S} . \mathrm{D}=0.73$ ) and 706 (Mean=2.77; S.D=0.67) respectively (Table 7).

\section{(II) Average duration of embankments repairing}

Respondents were asked to inform the average duration for repairing of breached embankments. 90.94\% respondents informed that it has been taken 1 week to 1 month. Only $4.33 \%$ respondents have replied that it has taken 1week. Few respondents (3.54\%) expressed their frustration and replied that it has been taken more than 1 year (Fig. 10).

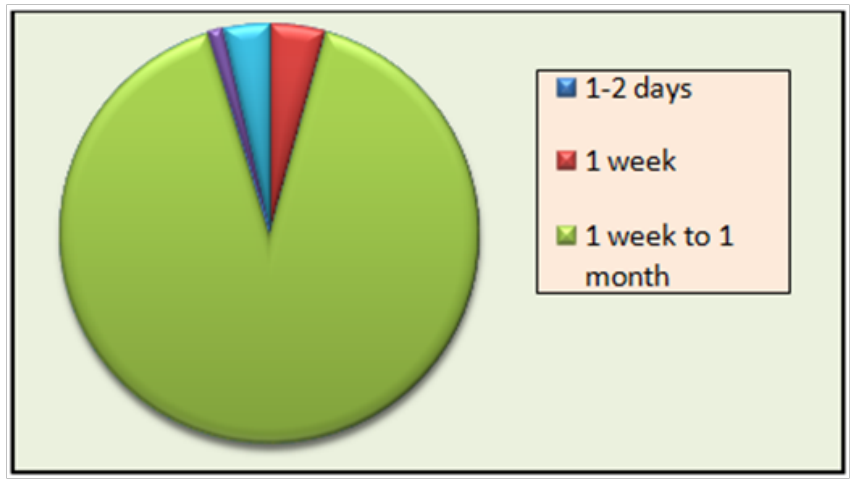

Figure 10 Average time for embankment repairing.

(III) Response on Govt. compensation for embankment breaching and related hazards

To understand the people's satisfaction level regarding the compensation for embankment breaching and other hazards. Result indicated that majority of the respondents $(55.91 \%)$ got nothing in the form of compensation. About $42.91 \%$ respondents replied that they have got compensation but it was not satisfactory. Only $1.18 \%$ respondents have shown their satisfaction about compensation they have received (Figure 11).

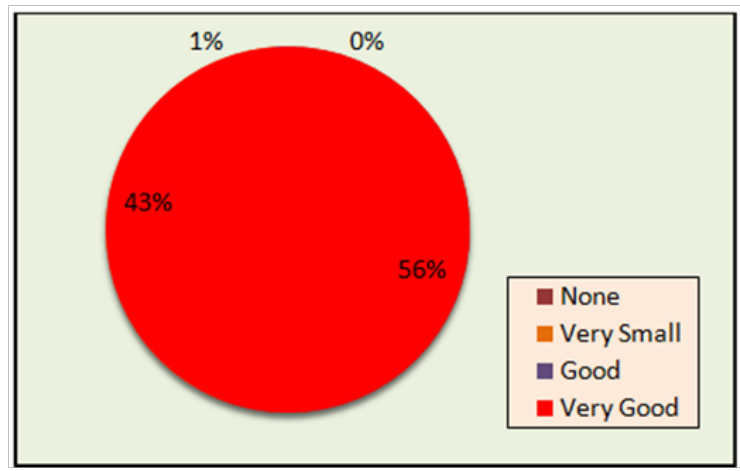

Figure I I Opinion on availability of Govt. assistance for breaching.

\section{(IV) Impacts of Aila, 2009}

Indian Sundarbans was severely affected by the Aila cyclone of 2009. People were asked to estimate their losses during Aila Cyclone. Only $4.72 \%$ respondents replied that they have lost nothing during Alia. Rest of the respondents have lost an amount ranges from two thousand to two lacks (Rs. 2000 to 200000). Highest no respondents (34.65\%) have lost an amount ranges from Rs20000 to 50000 (Figure 12).

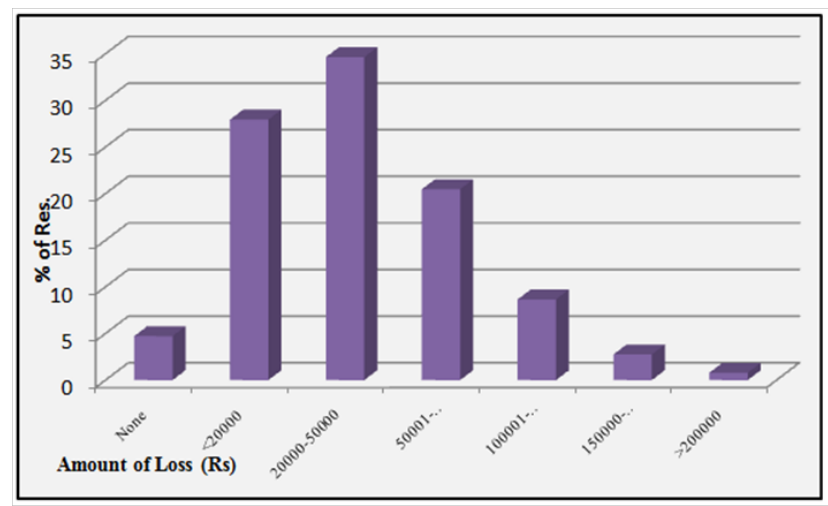

Figure 12 Reported economic loss in cyclone Aila.

\section{Health Hazards}

Land reclamation has a closed linked with various health problems that affect most of the areas of Sundarbans. To perceived common dieses of this area we asked people to identify most common dieses affecting their locality. Malaria and Typhoid were the two dieses identified by $75.20 \%$ and $67.72 \%$ respondents respectively. Other dieses were Diarrhea, Kidney's problems, Amebiasis, Dengue which has been recognized by $46.06 \%, 39.76 \%, 38.58 \%$ and $37.80 \%$ respondents respectively. Some respondents stated about Lungs, Nerve and Skin related dieses (Figure 13).

\section{Management Options}

\section{Respondents preferences of different precautionary measures for} hazard management

Sustainability of any management is largely depends on the involvement of local stakeholders into management practices. In this study our objectives were to know about public opinion and expectation on various hazard mitigation strategies. Various studies already established that local knowledge for any management is always effective because of its lower budget and co-operational 
benefits..$^{5-7}$ Along with that it also has long term direct observational experience that sometimes represents unknown consequences of any management practices, can't be separated through scientific models.

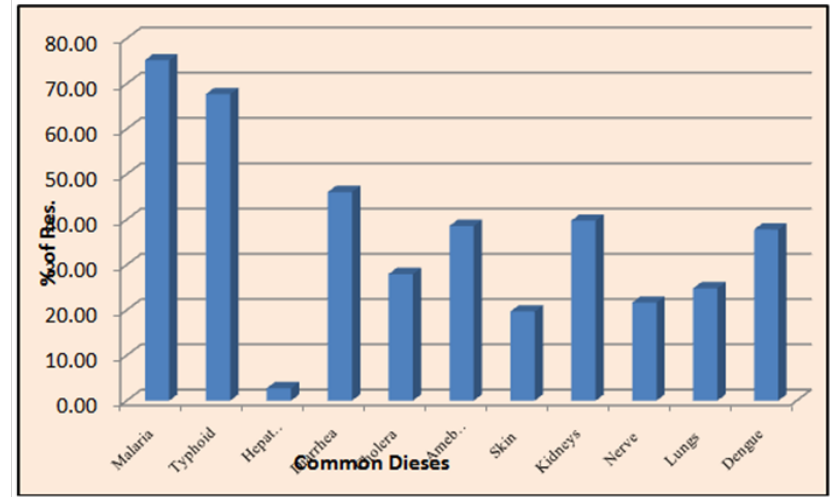

Figure 13 Most common diseases.

Structural and non-structural measures are the two popular hazard mitigation strategies adopted globally. Structural measures are associated with built infrastructure for flood protection, erosion control, storm protection etc. On the other hand non-structural measures are associates with natural protection through forest cover, wetlands, dunes etc. The best things of non-structural measure are its flexibility and self-adoptive capacity. Respondents were asked to express their view on management of their areas and they can state more than one option. Respondents also assured that they can suggest other management option not included in the list provided during survey. Construction of Pucca House and Elevating Houses were the two most common options which favoured by $98.03 \%$ and $91.73 \%$ respondents respectively. Both Mangrove Plantation and Keeping Hazard Updates have been supported by $79.53 \%$ respondents. Other two options Basement remaining opened in Monsoon months and Keeping hazard updates also approved by 64.57 and $58.66 \%$ respondents respectively (Figure 14).

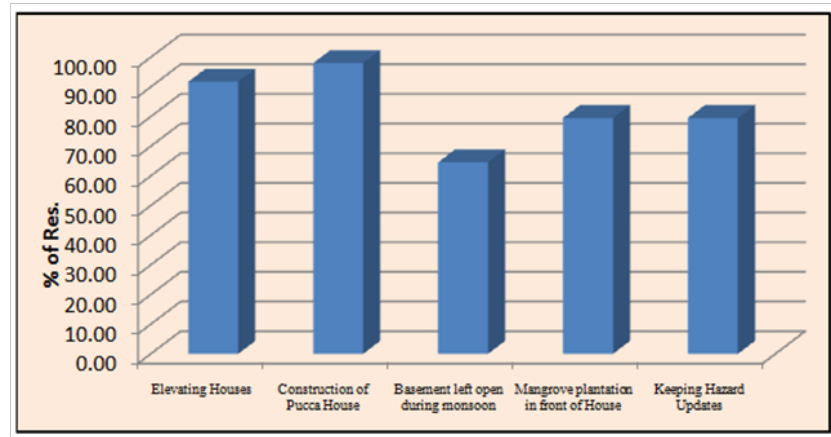

Figure 14 Opinion on precautionary measures.

There was no such difference on top two precautionary options between various occupational groups (Elevating Houses and Construction of Pucca House). All respondents from Prawn Collectors, Honey Collectors and Govt. Employee favoured the Elevating House option. Daily labour and Fisherman approvedthe Construction of Pucca house option.

In support of Basement opening, highest response (100\%) came from Govt. employee, Prawn Collectors and Honey collectors. Fisherman has lowest preference $(11.11 \%)$ on that. Regarding Mangrove Plantation, except Fisherman (33.33\%) all have shown significant responses in favour of that.
A wide range of differences of opinion (5.56\% to $100 \%)$ regarding Hazard Update have been recognized among the occupational categories. Expect Fisherman (5.56\%), Daily Labour (21.43\%) and others workers $(20 \%)$ all have given significant importance to that option. All Fisherman, Prawn collectors and Honey collectors have shown their interest about the 'Limiting livestock' option (Table 8).

\section{Response on future strategies}

Respondents were asked to state their future plan about their habitation. Most of the respondents (48.03\%) expressed that they will stay in their habitation if Govt. have taken effective hazard mitigation plans. The second highest option was 'Like to Live with Disaster', and $36.61 \%$ respondents replied in favoured of that, especially those who are economically weaker. Only $11.42 \%$ respondents stated that they wanted to leave their present location as early as possible and $3.94 \%$ seeking for rehabilitation (Figure 15).

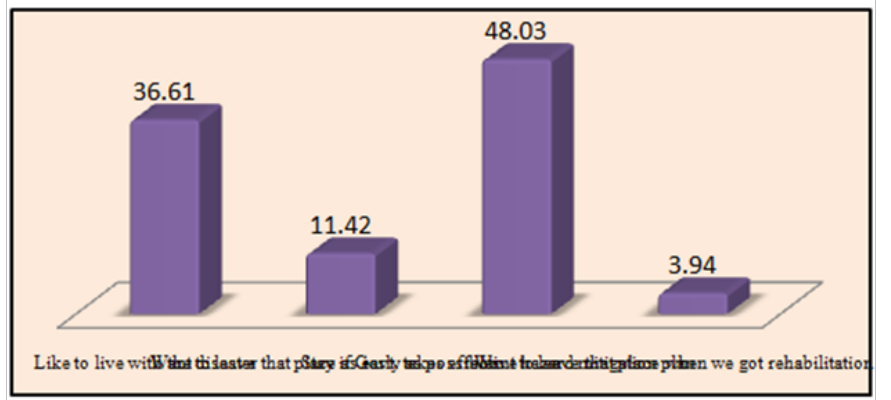

Figure 15 Opinion on future strategies.

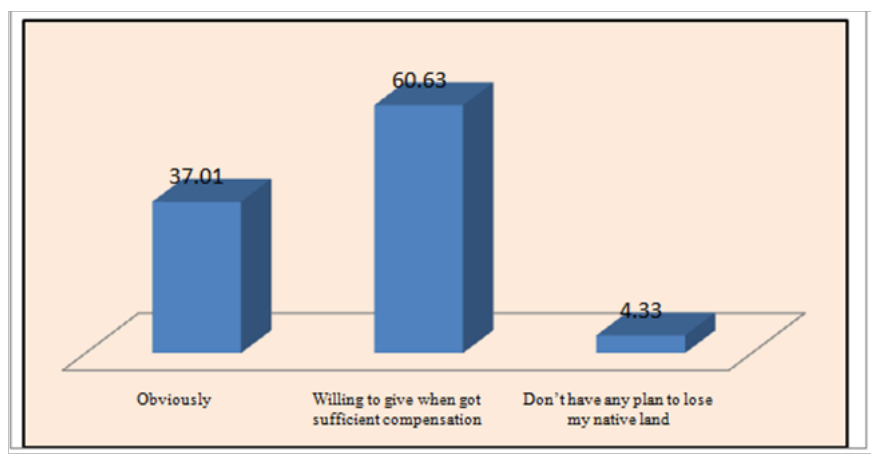

Figure I 6 Public willingness on land acquisition for embankment management.

A sharp variation has been observed among different occupational categories regarding future plan of their habitation. $100 \%$ respondents of Prawn Collector and Other Workers, $85 \%$ of Crab Collectors stated that they want to stay at their present location and like to live with the disasters. $50 \%$ respondents from Honey Collectors want to leave their place as early as possible. All of the Honey collectors and $80 \%$ Govt. Employee stated that they would stay if Govt. takes initiatives for hazard mitigation plans. Only $14.29 \%$ Daily Labour, $11.11 \%$ Fisherman and $9.88 \%$ Fishery Workers were willing to leave their places as early as possible (Table 9).

\section{Land Acquisition for embankment management}

Land always was the central issue for any project and future of any project also highly determined by the willingness of land owners. It has been seen that in many times, Govt. has to change or stop their project due to land conflict. Land is essential for any types of management either it has been using hard or soft technology. In this study majority of the respondents were go with the construction 
based management options with mangrove plantation. Both of these managements required large amount of land located along the present bank. As habitation of marginal Sundarbans mostly located along the bank, to implement such scheme, Govt. has to displace lot of people living over the banks. To get information regarding the willingness of people to give land for any project related to their interest, we made a survey on that. In this survey people were asked to state their willingness about land acquisition. About $60.63 \%$ respondents replied that they will give their land if compensation is acceptable. $37.01 \%$ respondents want to give land unconditionally and $4.33 \%$ don't agree to give their land (Figure 16).

Table 7 Opinion on areas most prone to erosion

\begin{tabular}{|c|c|c|c|c|c|c|c|c|c|c|}
\hline \multirow{2}{*}{ 을 음 } & \multicolumn{2}{|c|}{$\begin{array}{l}\text { ITA with Dense } \\
\text { Mangrove }\end{array}$} & \multicolumn{2}{|c|}{$\begin{array}{l}\text { ITA with Sparse } \\
\text { Mangrove }\end{array}$} & \multicolumn{2}{|c|}{$\begin{array}{l}\text { ITA without } \\
\text { Mangrove }\end{array}$} & \multicolumn{2}{|l|}{ No ITA } & \multicolumn{2}{|c|}{ Jetty Area } \\
\hline & $\begin{array}{l}\text { W. } \\
\text { Score }\end{array}$ & \% of Res. & $\begin{array}{l}\text { W. } \\
\text { Score }\end{array}$ & $\%$ of Res. & $\begin{array}{l}\text { W. } \\
\text { Score }\end{array}$ & $\%$ of Res. & $\begin{array}{l}\text { W. } \\
\text { Score }\end{array}$ & $\%$ of Res. & $\begin{array}{l}\text { W. } \\
\text { Score }\end{array}$ & $\%$ of Res. \\
\hline SA & 40 & 3.15 & 45 & 3.54 & 115 & 9.06 & 965 & 75.98 & 1100 & 86.61 \\
\hline$A$ & 8 & 0.79 & 24 & 2.36 & 84 & 8.27 & 128 & 12.60 & 80 & 7.87 \\
\hline $\mathrm{N}$ & 57 & 7.48 & 486 & 63.78 & 567 & 74.41 & 81 & 10.63 & 36 & 4.72 \\
\hline DA & 396 & 77.95 & 148 & 29.13 & 36 & 7.09 & 4 & 0.79 & 4 & 0.79 \\
\hline SD & 27 & 10.63 & 3 & 1.18 & 3 & 1.18 & 0 & 0.00 & 0 & 0.00 \\
\hline DR & 0 & 0 & 0 & 0 & 0 & 0.00 & 0 & 0.00 & 0 & 0.00 \\
\hline Sum & 528 & 100 & 706 & 100 & 805 & 100 & 1178 & 100 & 1220 & 100 \\
\hline Mean & 2.07 & & 2.77 & & 3.16 & & 4.63 & & 4.80 & \\
\hline Sd & 0.70 & & 0.67 & & 0.73 & & 0.70 & & 0.54 & \\
\hline
\end{tabular}

Table 8 Occupation wise preferred precautionary measures

\begin{tabular}{|c|c|c|c|c|c|c|c|c|c|}
\hline \multirow{2}{*}{$\begin{array}{l}\text { Management } \\
\text { Option }\end{array}$} & \multicolumn{9}{|c|}{$\%$ of Respondents } \\
\hline & $\begin{array}{l}\text { Crab } \\
\text { Collec. }\end{array}$ & Cultivator & $\begin{array}{l}\text { Daily } \\
\text { Labour }\end{array}$ & Fisherman & $\begin{array}{l}\text { Govt. } \\
\text { Employee }\end{array}$ & $\begin{array}{l}\text { Prawn } \\
\text { Collec. }\end{array}$ & $\begin{array}{l}\text { Honey } \\
\text { Collec. }\end{array}$ & $\begin{array}{l}\text { Fishery } \\
\text { Work }\end{array}$ & Others \\
\hline Elevating Houses & 95 & 93.68 & 85.71 & 94.44 & 100 & 100 & 100 & 93.75 & 80 \\
\hline $\begin{array}{l}\text { Construction of } \\
\text { Pucca House }\end{array}$ & 97.5 & 96.84 & 100 & 100 & 100 & 100 & 100 & 100 & 100 \\
\hline $\begin{array}{l}\text { Basement left } \\
\text { open during } \\
\text { Monsoon }\end{array}$ & 60 & 72.63 & 21.43 & II.II & 100 & 100 & 100 & 96.88 & 20 \\
\hline $\begin{array}{l}\text { Mangrove } \\
\text { plantation in front } \\
\text { of House }\end{array}$ & 75 & 84.21 & 71.43 & 33.33 & 100 & 100 & 100 & 100 & 80 \\
\hline $\begin{array}{l}\text { Keeping Hazard } \\
\text { Updates }\end{array}$ & 57.5 & 68.42 & 21.43 & 5.56 & 100 & 100 & 100 & 93.75 & 20 \\
\hline Limiting livestock & 55 & 64.21 & 21.43 & 0 & 100 & 100 & 100 & 93.75 & 20 \\
\hline
\end{tabular}

Table 9 Future strategies of different occupational groups

\begin{tabular}{|c|c|c|c|c|c|c|c|c|c|}
\hline Options & $\begin{array}{l}\text { Crab- } \\
\text { Coll. }\end{array}$ & Cul. & $\begin{array}{l}\text { Daily } \\
\text { Lab }\end{array}$ & Fisherman & $\begin{array}{l}\text { Govt. } \\
\text { Em. }\end{array}$ & $\begin{array}{l}\text { Prawn } \\
\text { Col. }\end{array}$ & $\begin{array}{l}\text { Hon- } \\
\text { Col }\end{array}$ & $\begin{array}{l}\text { Fishery } \\
\text { Work. }\end{array}$ & Others \\
\hline Like to live with Disasters & 85 & 37 & 42.83 & 50 & 20 & 100 & 0 & 15.63 & 100 \\
\hline $\begin{array}{l}\text { Want to Leave that Place as } \\
\text { Early as Possible }\end{array}$ & 12.50 & 06 & 21.43 & 22.22 & 0 & 0 & 50 & 12.50 & 0 \\
\hline $\begin{array}{l}\text { Stay if Govt. takes Effective } \\
\text { Hazard Mitigation Plans }\end{array}$ & 46.25 & 51 & 21.43 & 16.67 & 80 & 0 & 100 & 59.88 & 0 \\
\hline $\begin{array}{l}\text { Want to Leave that Place When } \\
\text { We Got Rehabilitation }\end{array}$ & 6.25 & 04 & 14.29 & 11.11 & 0 & 0 & 0 & 9.88 & 0 \\
\hline
\end{tabular}

\section{Conclusion}

Public perception becomes an important strategy for hazard mitigation of an area. Practical implementation of any management strategy can't be possible without active cooperation of the stakeholders. In this paper we have analysed the public perception and opinion on various problems related to this area. Probable causes and consequences are also represented here. This is one of the first attempt of household level identification and assessment of various hazards. These opinions can be taken under consideration for the formulation of future plane for this area.

\section{Acknowledgement \& funding}

The authors would like to thank University Grant Commission (UGC) for their financial assistance. The authors are also thankful to the people of Sundarbans for providing essential data. 


\section{Conflicts of interest}

Author has declared no conflict of interest.

\section{References}

1. Asmawi MZ, Ibrahim AN., The perception of community on coastal erosion issue in Selangor, Malaysia. Journal of Clean Energy Technologies. 2013;1(3):164-168.

2. Thomalla F, Downing T, Spanger-Siegfried E, et al. Reducing hazard vulnerability: Towards a common approach between disaster risk reduction and climate adaptation. Disasters. 2006;30(1):39-48.

3. Tran KC, Euan J, Isla ML. Public perception of development issues: impact of water pollution on a small coastal community. Ocean \& Coastal Management. 2002;45(6-7):405-420.
4. Du Toit JT. Wildlife harvesting guidelines for community based wildlife management: a southern African perspective. Biodiversity and Conservation. 2002;11:1403-1416.

5. Floyd DL, Prentice-Dunn S, Rogers RW. A meta-analysis of research on protection motivation theory. J Appl Soc Psychol. 2000;30(2):407-429.

6. Grothmann T, Reusswig F. People at risk of flooding: why some residents take precautionary action while others do not. Nat. Hazards. 2006;38:101-120.

7. Koerth J, Jones N, Vafeidis AT, et al. Household adaptation and intention to adapt to coastal flooding in the Axios - Loudias - Aliakmonas National Park, Greece. Ocean and coastal Management. 2013;82:43-50. 